\title{
HOW TO INCREASE CUSTOMER REPURCHASE INTENTION IN AN ONLINE RETAILING STORE? AN EXTENDED EXPECTATION CONFIRMATORY MODEL
}

\author{
Putu Wuri Handayani \\ Faculty of Computer Science \\ Universitas Indonesia \\ putu.wuri@cs.ui.ac.id \\ I Made Eka Ariantana \\ Faculty of Computer Science \\ Universitas Indonesia \\ made.eka.ariantana@ui.ac.id \\ Ave Adriana Pinem \\ Faculty of Computer Science \\ Universitas Indonesia \\ ave.pinem@cs.ui.ac.id
}

\begin{abstract}
This research investigates factors driving customers repurchase intention for one of Indonesia's largest online bookstores. Online retailing has grown in line with the increasing number of internet users in Indonesia. The number of new customers on websites is increasing, but although the investigated company profits more from recurrent customers than new ones, this bookstore has difficulty retaining customers. To address this, we extend the expectation confirmatory model, using the site quality and regret variables. We collected data from customers who had bought products from the company website; the analysis employed the structural equation modeling approach. The results showed that customer satisfaction, customer trust, and regret directly affect repurchase intention. Site quality and confirmation are factors that indirectly affect repurchase intention. To retain existing customers, the company should improve its website design, enhance the payment and delivery options, and add a discussion forum and customer service features.

Keywords: e-Commerce, online retail, expectation confirmation model, repurchase intention, structural equation modeling

\section{INTRODUCTION}

The advancement of information technology currently affected various aspects of life, including the business world. One such advancement involves the internet as the driving factor of e-commerce development. In their Total Retail Survey 2017, PricewaterhouseCoopers $(\mathrm{PwC})$ mentioned that books, music, movies, and video games are the most popular items on online stores.
\end{abstract}


One of the largest online bookstores in Indonesia is XYZ.com established in 2015 where XYZ bookstore was established in 1970. Although XYZ bookstore has long been established and already has an online bookstore but sales transactions from online bookstores have not shown satisfactory results. The company data show that the profits earned from recurrent customers represented about $67 \%$ of the profits in 2017. This condition aligns with several studies, which have found that recurrent customers' purchases contribute fivefold profits to a business compared with purchases made by new customers [1]; thus, retaining existing customers is more valuable than finding new ones [2]. To achieve the company's target, XYZ.com should ideally increase the number of members who engage in recurrent transactions. Thus, the company need to make improvements relate to the website design, purchasing procedures, and payment system.

The quality of the website is an important marketing tool for encouraging positive behavior; it represents an important factor for customer satisfaction and customer trust [3]. The quality of internet shopping sites can be conceptualized as a combination of six dimensions, as follows: shopping convenience, site design, information usefulness, transaction security, the payment system, and communication [3].

The expectation confirmation model (ECM) has proven to be appropriate for explaining the continued use of a system [4]. The ECM can be used as a reference for continuous usage in research on e-commerce websites, as an e-commerce website is a type of information system using information technology as an implementation tool. It is important for online retail store to determine which factors drive customers to repurchase on their site from the technology and user experience perspectives, and the ECM can help in accomplishing this. However, in this study we adopt the website quality, the main marketing tool in online retail store, as the factor that influence the customer satisfaction and trust as stated before [3]. Therefore, the model of customer repurchase intention could be capture comprehensively. Furthermore, due to the limited research related to the implementation of e-commerce in Indonesia, the present research is expected to be useful as a guide for the business to customer (B2C) model in Indonesia, specifically in the book retail industry.

This paper is organized as follows: Section 2 reviews the existing literature, while Section 3 describes the conceptual model. Section 4 explains the research methodology. The results and discussions of this research are subsequently elaborated on in Sections 5 and 6. Section 7 explores the implications of this research, and the final section discusses conclusions and recommendations for future work related to this research.

\section{LITERATURE REVIEW}

\subsection{Online Retail in Indonesia}

Online retail is a form of Business to Customer (B2C) commerce. It is like the traditional retail, but the main difference is that media are used to run the business via the internet [5]. Basically, B2C e-commerce comprises shops that focus on selling products online so that the profit or loss is borne by the company. By directly selling to customers and reducing "the middleman," the company can lower prices to gain greater profits. B2C businesses must maintain good relationships with their customers 
so that they feel satisfied and make recurrent purchases. B2C e-commerce is a complex process because the business must ensure good management of supply and demand for maintaining customer satisfaction.

With the number of internet users reaching 132.7 million, representing $51.8 \%$ of the total population of Indonesia (256 million in 2016), the e-commerce market is tempting for some business owners, who can see its potential for the future [6]. The statistics concerning the Indonesian e-commerce growth are promising, with increasing revenues in various markets. Electronics and media is the market with the second highest revenue [7]. The growth of this electronics market is forecasted to reach $18.26 \%$ in 2018 .

\subsection{Site Quality}

The website quality directly affects the customer's perception of purchasing through an e-commerce site; thus, this is considered a key factor in the e-commerce market [8]. Research on website quality has been conducted in many areas. The dimensions of website quality have also been found to vary. As mentioned above, in internet shopping, the quality of the sites comprises six dimensions, namely shopping convenience, site design, information usefulness, transaction security, the payment system, and communication [3]. Shopping convenience has been studied as one of the reasons that buyers enjoy online shopping [3]. Site design is the physical environment of an online store that has a positive effect on consumer. Before consumers buy a product, they try to find information about the products; thus, informativeness can be an important factor when shoppers visit online retail sites. The security of online transaction systems and privacy protection are also essential when it comes to increasing online purchases. In addition, when consumers visit retail sites to buy a product, they tend to seek reviews from other shoppers as online shoppers tend to prefer building community via the internet, thereby making communication an important factor.

\subsection{The Expectation Confirmation Model}

The ECM is a model developed by [4] that focuses on the sustainable use of information systems [9]. The user's intention to use information systems is continuously influenced by three elements, namely the user satisfaction level, confirmation of expectations, and perceived benefits [9]. The process in making the decision to repurchase a product begins with an initial decision or expectations. Expectations take the form of perceived usefulness and confirmation, by which the user then assesses the performance through the experience when utilizing the information systems. If the user finds that the information system is useful, as expected, there will be a sense of satisfaction that affects the purpose of continuous use of the information system, also called continuance intention [4].

\subsection{Previous Studies}

Some previous research that has been conducted were sought through online databases to get references for the research model. The inclusion criterion of this study is the literature that discusses repurchase intention in e-Commerce, especially B2C. Some of the most relevant studies are [3], [10], [11] and [12]. The first study 
aims to determine the effect of site quality on repurchase intention to shop online. This study explains the relationship between site quality, customer satisfaction, customer trust, customer commitment, and repurchase intention in the context of online shopping [3]. The second study aims to form a repurchase intention model on B2C e-Commerce based on the DeLone \& McLean IS Success Model to test the relationship between website quality, internet shopping value, customer trust, customer satisfaction, and customer repurchase intention. The third study looked for how utilitarian factors (perceived ease of use and perceived usefulness), hedonic factors (perceived pleasure/enjoyment), social/psychological factors (confirmation, satisfaction and trust) directly or not affect consumers continuance intention in the context of shopping online. The fourth study adopted the expectancy confirmation theory and regret theory to look for the influence of external references on repurchase intention behavior and explore how customer search efforts affect satisfaction and regret.

This study aims to determine the factors that influence the repurchase intention of consumers in an online retail in terms of the quality of the website and user experience. Thus, website quality and user experience are very important factors to be examined in this study. The quality of internet shopping sites can be conceptualized as a combination of six dimensions including shopping convenience, site design, information usefulness, transaction security, payment systems, and communication [3]. In the Expectation Confirmation model, confirmation/disconfirmation refers to assessments or evaluations made by someone regarding a product, service, or technology. When expectations are in accordance with reality, it will give satisfaction to customers, conversely, if expectations are not in accordance with reality, it will lead to regret. Then the confirmation, regret, customer satisfaction, and customer trust variables can explain the user experience of an online retail store. These variables are adopted to formulate the conceptual model.

\section{CONCEPTUAL MODEL}

This study aims to identify the factors that affect the repurchase intention in an online retail store. For this study, the authors use the ECM as the foundation for forming a theoretical framework, as the research focuses on analyzing organization subscribers' behavior post-acceptance and utilization. In addition, the ECM has proven to be an appropriate model for explaining sustainable use in the future [4]. The model can be used as a reference for research on continuous utilization of e-commerce websites, considering e-commerce websites as a form of utilizing information systems via information technology as an implementation tool. Furthermore, the authors modify the ECM by integrating two perspectives, namely technology and user experience.

There is one variable of the ECM that is not included in this research-perceived usefulness - as the usability perspective has been defined with site quality variables. In terms of the site quality indicators described, the XYZ.com, as the case study of this research, website page provides clear information for facilitating customers' book searches, ordering procedures, and payment systems, thereby speeding up the transaction process. According to [3], the quality of internet shopping sites can be conceptualized as a combination of six dimensions, namely shopping convenience, site design, information usefulness, transaction security, the payment system, and 
communication. Thus, identifying the site quality dimension is extremely important for consumer assessment.

The quality of the website is an important marketing tool encouraging positive behavior; it represents important factors for eliciting customer satisfaction and trust [3]. This is in line with other studies that have identified the effects of the e-service quality on e-satisfaction and perceived website quality on e-trust [13]. Therefore, there are two hypotheses related to site quality that can be derived in this research model, as follows:

\section{H1: Site quality positively affects customer satisfaction.}

\section{H2: Site quality positively affects trust.}

In the ECM, confirmation/disconfirmation refers to an individual's judgment or evaluation of a product, service, or technology. The evaluation or assessment is carried out by comparing the experience with expectations. When a product, service, or technology performs according to the consumer's expectations, there is a confirmation of hope, which is used to maintain satisfaction. This is reinforced by the results in [12], in which the authors discussed the confirmation effect on satisfaction and repurchase intention; thus, the confirmation variable is used in this research model. The findings in [12] show that confirmation has a great effect on regret; thus, failure to meet customers' expectations not only reduces their satisfaction, but also causes customers to regret their purchases. Customers who have a bad experience will have a low intention to repurchase from the same seller. Thus, regret is also used as a variable in this research model. Therefore, in relation to the customer experience, the two following hypotheses are derived:

\section{H3: Confirmation has a positive effect on customer satisfaction.}

\section{H4: Confirmation negatively affects regret.}

According to the ECM, customer repurchase intention is influenced by the satisfaction gained during the transaction. DeLone and McLean updated the information system model of success, and the ECM states that customer satisfaction is related to customers' assessment of the experience gained while using the information system [13]. In [3], it was mentioned that customer trust and customer commitment are positively associated with repurchase intention. This implies that customer trust and customer commitment are important factors for encouraging more positive repurchase intentions. Thus, customer trust is used in this research as a factor affecting customer repurchase intention. Trust is defined as the customer's attitude based on the expectation that the service provider will deliver the promised product or service, regardless of all the risks the customers will face. A good experience gained by customers can increase the level of customer confidence in the service provider [14]. Customer satisfaction is related to the customer's experience during the use of information systems [15]. Thus, customer satisfaction can be considered as a factor that affects customer trust, and the following hypotheses are developed:

H5: Customer satisfaction positively affects repurchase intention.

H6: Trust positively affects repurchase intention.

H7: Customer satisfaction positively affects trust. 
According to [16], regret is an emotion that a person experiences when realizing or imagining that the current situation could have been better if he or she had decided differently. The results in [12] suggest that the consumer's repurchasing intention is primarily influenced by satisfaction, and subsequently, regret. Therefore, satisfied customers tend to repurchase from the same sellers, while regretful customers will have a low intention to repurchase from the same seller. Thus, the following hypotheses are developed:

\section{H8: Regret negatively affects repurchase intention.}

\section{H9: Regret negatively affects customer satisfaction.}

From the above explanation, the research model for this study is visualized in Figure 1.

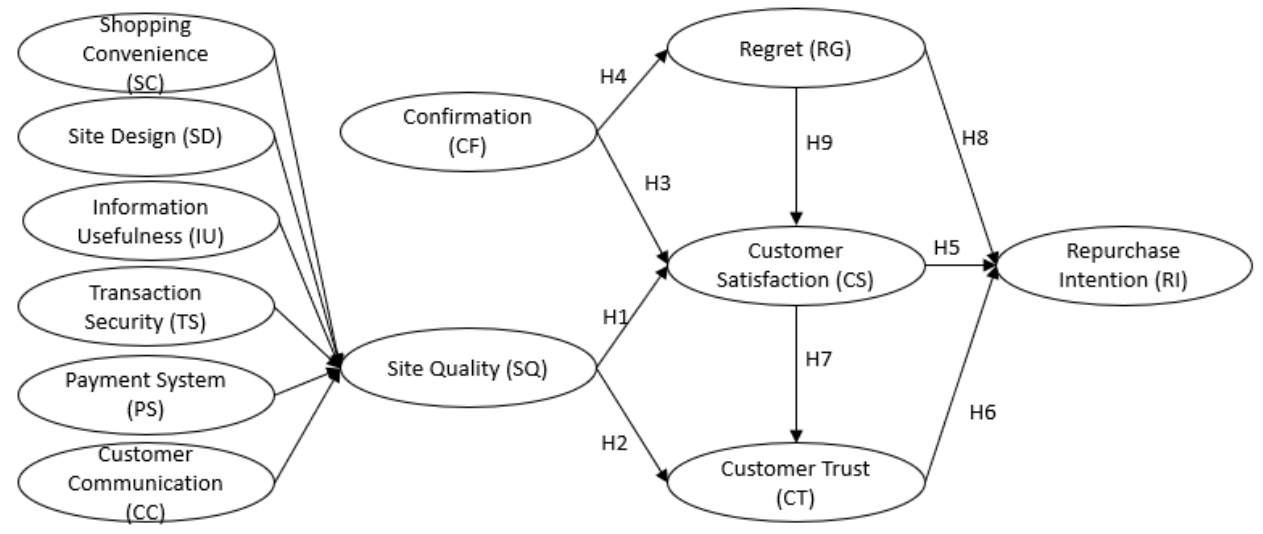

Figure 1 Proposed model

\section{METHODOLOGY}

The sample of this study is XYZ.com as one of the largest online bookstores in Indonesia. It was established in 2015 where XYZ bookstore was established in 1970. Compared to other competitors $\mathrm{XYZ}$ is very successful in attracting consumers and is the largest retail network in Indonesia in book sales. Although XYZ bookstore has long been established and already has an online bookstore but sales transactions from online bookstores have not shown satisfactory results. In 2015-2017, XYZ.com had 133,255 members, and 80,880 members $(60.7 \%)$ had conducted a transaction on XYZ.com. However, only 27,800 members (34\%) made recurring purchases. This situation will not support the company targets for 2018. Thus, the evaluation of the driving force of customer repurchase intention must be conducted.

The approach of this study is a quantitative approach using a questionnaire to collect the data. The questions in the questionnaire list are based on the research model variables, which were identified by determining indicators developed in previous studies. The answer to each question is measured using a 5-point Likert scale with the following possible responses: strongly disagree, disagree, neutral, agree, and strongly agree. A draft questionnaire was generated at the stage of preparing quantitative data collection instruments, and then a readability test was carried out. The readability test was conducted with five respondents who had made at least one transactions on XYZ.com and had experience in developing questionnaires. The respondents then gave criticism and suggestions concerning the statements in the 
questionnaire. Most suggested changing words or sentences that were imprecise and ambiguous. Further improvements were made to the sentences in the questionnaire based on these critiques.

After the legibility test, the authors collected five hundred of user email provided by the organization. All the provided emails were contacted to fill in the online questionnaires (available at http://kuesioner.cs.ui.ac.id/gramediadotcom/). To reach the research sample, the researcher used the nonprobability sampling technique (a non-random method) of purposive sampling. Purposive sampling limits the sample to certain types of people who can provide the information. Data were collected for 3 weeks through the questionnaire link, and 199 questionnaires were submitted. Thus, the response rate was 39\%. The reason of nonresponse is predicted because the email was not read, and the user is not available for the research. However, after the filtering process, 24 questionnaires had to be removed because of duplication of the data. Thus, 172 questionnaires were used for the data analysis process. This sample number is enough since the minimum number for fourteen paths model is 140 [17].

This study used questionnaires with positive and negative sentences. Following [18], this was done to avoid respondents who originally answered and avoid subjective statements. The values were changed by reversing the results of the entire content; as [18] stated, that way to include sentences with different meanings on one measurement scale is to reverse the value of the sentences so that the scale has good quality. The collected quantitative data were then analyzed by using structural equation model (SEM) analysis. SEM was used to test the validity of the theoretical framework proposed in this study, as well as the proposed hypothesis. In this study, the authors used the Partial Least Square (PLS) SEM approach because the research model studied has a formative construct, which is the relationship between the second-order construct and the first-order construct as an indicator. In addition, the collected data was analyzed for the normality test and the result was failed to prove so. Since PLS-SEM generally makes no assumptions about the data distribution then this method was suitable for this case [17]. PLS-SEM is also recommended to analyze an exploratory model [17] like the author developed in this research.

This research used the WarpPLS tool to perform SEM analysis with the PLS approach. PLS recognizes two types of components in the causal model, namely measurement model and the structural model. The structural model consists of two types of latent constructs that cannot be observed-first-order and second-order constructs. In contrast, the measurement model consists of indicators that can be observed. In this test, we also estimated the path coefficients, which identify the strength of the relationship between the independent and dependent variables. The measurement model consisted of the relationship of observable indicators and the first-order constructs measured by those indicators, followed by the second-order construct as measured by the first-order construct as the indicator.

\section{RESULTS}

\subsection{Respondent Demographics}

The summary of respondents' demographics in this study is given in Table 1 . Most respondents were young, with ages ranging from 20 to 29 years, as young buyers prefer to buy books online, rather than in physical bookstores. 
Table 1. Respondents' Demographics

\begin{tabular}{llll}
\hline Characteristics & $\mathrm{N}=172$ & Percent \\
\hline Age & $<20$ years & 4 & $2.3 \%$ \\
\cline { 2 - 4 } & $20-29$ years & 129 & $75.4 \%$ \\
\cline { 2 - 4 } & $30-39$ years old & 37 & $21.1 \%$ \\
\cline { 2 - 4 } & 40-49 years old & 2 & $1.1 \%$ \\
\cline { 2 - 4 }$>50$ years old & 0 & $0 \%$ \\
\hline \multirow{4}{*}{ Gender } & Male & 82 & $48 \%$ \\
\cline { 2 - 4 } & Female & 90 & $52 \%$ \\
\hline Education & Diploma & 33 & $19 \%$ \\
\cline { 2 - 4 } Level & Bachelor & 123 & $70 \%$ \\
\cline { 2 - 4 } & Master & 7 & $4 \%$ \\
\cline { 2 - 4 } & Doctor & 0 & $0 \%$ \\
\cline { 2 - 4 } & Other & 12 & $7 \%$ \\
\hline \multirow{2}{*}{ Shopping } & $1-5$ times & 146 & $83 \%$ \\
\cline { 2 - 4 } Frequency & $6-10$ times & 28 & $16 \%$ \\
\cline { 2 - 4 } & $11-15$ times & 1 & $1 \%$ \\
\cline { 2 - 4 } & $16-20$ times & 0 & $0 \%$ \\
\cline { 2 - 4 } & $>20$ times & 0 & $0 \%$ \\
\hline
\end{tabular}

\subsection{Measurement and Structural Model Evaluation}

An outer model evaluation, or measurement model, was performed to assess the validity and reliability of the model. The evaluation involved two stages: The first was evaluation of the first-order constructs formed by their indicators and evaluation of the second-order constructs formed by the first-order construct as their dimension. After processing the data using WarpPLS, the results of the outer loading values for each indicator in the latent variables in the research model were presented. From the results of the data processing with WarpPLS, almost all indicators on each variable had a loading value greater than 0.70 , and there was only one indicator that had a loading value less than 0.70 , which was PS4, which had a loading factor of 0.642 . Thus, this indicator was eliminated.

A good Averaged Value Extracted (AVE) value requires a value greater than 0.50 [18]. The AVE values of all the constructs were greater than 0.50 , with the smallest value of 0.830 for the site design variable and the largest of 0.962 for the transaction security variable. The values of composite reliability and Cronbach's alpha for all constructs were shown to be above 0.70 . Thus, it can be concluded that all the constructs had good reliability. The R2 results for the endogenous latent variables in Table 2 show that the R2 values were in the range of values of 0.464 0.709. In this research model, there was one moderate variable (regret, RG) and three strong variables (customer satisfaction [CS], customer trust [CT], and repurchase intention $[\mathrm{RI}]$ ) as the $\mathrm{R} 2$ approached the value of 0.67 . This coefficient of determination showed that the value of $\mathrm{R} 2$ for the endogenous variable of RI was 0.666 , indicating that $66.6 \%$ of the variation in the RI data was influenced by CS, CT, and RG in the research model. 
Table 2. Value of AVE, CR, CA, and $\mathrm{R}^{2}$

\begin{tabular}{|c|c|c|c|c|c|c|c|c|c|c|c|c|c|c|c|}
\hline & SC & SD & IU & TS & PS & $\mathrm{CC}$ & CF & CS & CT & RG & RI & AVE & $C R$ & $C A$ & $R^{2}$ \\
\hline SC & 0.949 & & & & & & & & & & & 0.901 & 0.973 & 0.964 & - \\
\hline SD & 0.850 & 0.911 & & & & & & & & & & 0.830 & 0.951 & 0.931 & - \\
\hline IU & 0.707 & 0.790 & 0.955 & & & & & & & & & 0.912 & 0.976 & 0.968 & - \\
\hline TS & 0.634 & 0.732 & 0.681 & 0.981 & & & & & & & & 0.962 & 0.990 & 0.987 & - \\
\hline PS & 0.783 & 0.837 & 0.760 & 0.726 & 0.936 & & & & & & & 0.876 & 0.955 & 0.929 & - \\
\hline $\mathrm{CC}$ & 0.624 & 0.726 & 0.748 & 0.683 & 0.683 & 0.969 & & & & & & 0.939 & 0.984 & 0.978 & - \\
\hline CF & 0.697 & 0.778 & 0.688 & 0.686 & 0.721 & 0.818 & 0.977 & & & & & 0.954 & 0.984 & 0.976 & - \\
\hline CS & 0.627 & 0.717 & 0.598 & 0.654 & 0.704 & 0.696 & 0.778 & 0.968 & & & & 0.937 & 0.978 & 0.967 & 0.673 \\
\hline CT & 0.656 & 0.700 & 0.716 & 0.639 & 0.759 & 0.730 & 0.752 & 0.727 & 0.920 & & & 0.846 & 0.957 & 0.939 & 0.709 \\
\hline RG & 0.471 & 0.565 & 0.443 & 0.394 & 0.503 & 0.461 & 0.552 & 0.453 & 0.462 & 0.947 & & 0.897 & 0.963 & 0.941 & 0.464 \\
\hline RI & 0.567 & 0.629 & 0.646 & 0.566 & 0.667 & 0.733 & 0.761 & 0.701 & 0.742 & 0.535 & 0.943 & 0.890 & 0.960 & 0.938 & 0.666 \\
\hline
\end{tabular}


The evaluation of the second-order construct was performed from the second-order construct to the first-order construct, which became its dimension. In WarpPLS, the repeated indicators approach can be carried out by modifying the first-order construct into a second-order construct indicator; thus, the factor value of the first-order construct will be the indicator value for the second-order construct [19]. According to [19], WarpPLS can be used to measure the weight significance of constructs or latent variables in formative form by looking at the p-value [19]. An item or indicator is considered valid if it has a p-value less than 0.05 [19]. From the p-values in Table 3, it is clear that all the indicators of site quality (SQ; shopping convenience, site design, information usefulness, transaction security, payment system, customer communication) were significant at the level of $0.001(\mathrm{p}<0.001)$, thereby indicating that all indicators were valid for measuring the second-order construct.

Table 3. Weight Indicators

\begin{tabular}{|c|c|c|c|c|c|}
\hline $\begin{array}{l}\text { Construct } \\
\text { order }\end{array}$ & $2^{\text {nd }}$ & $\begin{array}{l}\text { Construct } \\
\text { order }\end{array}$ & Weight & $p$-value & VIF \\
\hline \multirow{6}{*}{ SQ } & & 1v_SC & 0.187 & $<0.001$ & 3.852 \\
\hline & & lv_SD & 0.201 & $<0.001$ & 6.124 \\
\hline & & lv_IU & 0.190 & $<0.001$ & 3.435 \\
\hline & & lv_TS & 0.180 & $<0.001$ & 2.593 \\
\hline & & 1v_PS & 0.195 & $<0.001$ & 4.134 \\
\hline & & lv_CC & 0.181 & $<0.001$ & 2.728 \\
\hline
\end{tabular}

\subsection{Path Coefficient and Hypothesis Testing}

The results of the path coefficient calculation in the research model in Table 6 show that the coefficient value was in the range of 0.011-0.681. A path coefficient value below 0.1 is considered insignificant, while values greater than 0.1 are significant and comparable. Therefore, almost all paths have a coefficient value greater than 0.1 , except for one path with low significance, which has a value of 0.011 in the $\mathrm{RG} \rightarrow \mathrm{CS}$. The value of f2 in this path is also considered low, at 0.005. A path with an independent construct has a medium effect on the dependent variable, with an $\mathrm{f} 2$ value of 0.097 . Seven paths with dependent constructs have a large influence on the dependent construct, with $\mathrm{f} 2$ values close to 0.35 , as follows: SQ $\rightarrow \mathrm{CS}$ (0.291), SQ $\rightarrow \mathrm{CT}$ (0.415), CF $\rightarrow \mathrm{RG}(0.464), \mathrm{CF} \rightarrow$ $\mathrm{CS}$ (0.377), CS $\rightarrow$ CT (0.293), CS $\rightarrow$ RI (0.293), and CT $\rightarrow$ RI (0.276). Figure 2 summarizes the PLS estimation model results from the proposed research model. 


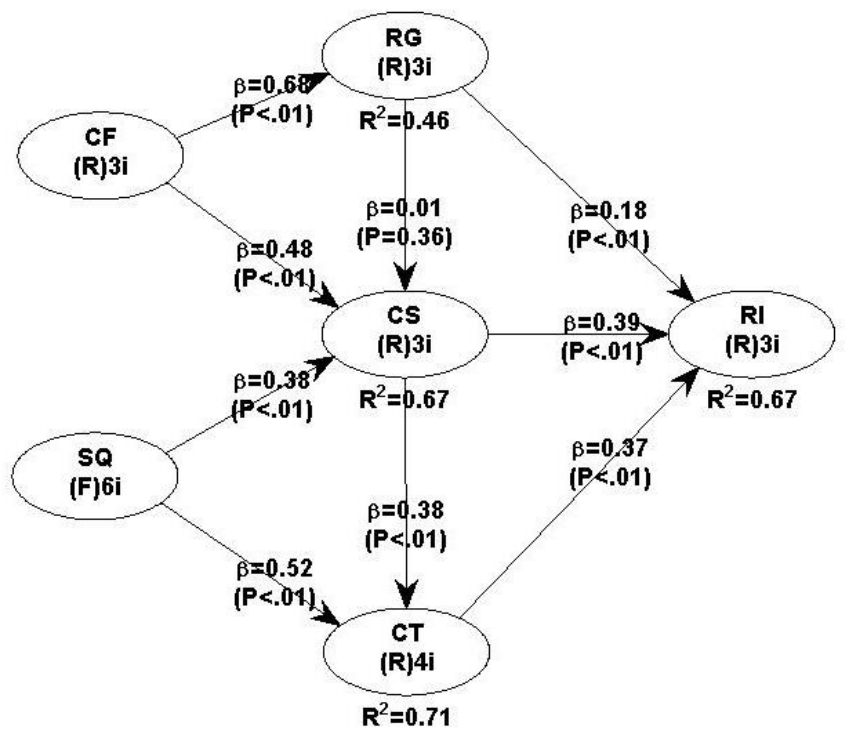

Figure 2 Structural model result

The Goodness of Fitness Index $(\mathrm{GoF})$ value generated from the WarpPLS output was 0.745 ; thus, the overall model in this study is considered to have good fit because it has a GoF value $>0.36$. The testing phase of this hypothesis was done after the structural model evaluation stage. Path coefficient values below 0.1 are considered insignificant, while a value greater than 0.1 represents a significant value. Another consideration was to use a significance value of at least $\alpha=0.05$, so it is considered significant if the p-value is less than 0.05 . Hence, the hypothesis is accepted if the path coefficient value is greater than 0.1 and the p-value is less than 0.05 . Table 4 shows the hypothesis testing results for the research model.

Table 4 Path Coefficient, Cohen Effect, and Hypothesis Testing

\begin{tabular}{llllll}
\hline $\begin{array}{l}\text { Hypo } \\
\text { thesis }\end{array}$ & Path & $\begin{array}{l}\text { Path } \\
\text { Coefficient }\end{array}$ & $\begin{array}{l}\text { Cohen } \\
\text { Effect }\left(\mathbf{f}^{\mathbf{2}}\right)\end{array}$ & $\boldsymbol{p}$-value & $\begin{array}{l}\text { Hypothesis } \\
\text { Testing }\end{array}$ \\
\hline $\mathrm{H} 1$ & $\mathrm{SQ} \rightarrow \mathrm{CS}$ & 0.376 & 0.291 & $<0.001$ & Accepted \\
\hline $\mathrm{H} 2$ & $\mathrm{SQ} \rightarrow \mathrm{CT}$ & 0.515 & 0.415 & $<0.001$ & Accepted \\
\hline $\mathrm{H} 3$ & $\mathrm{CF} \rightarrow \mathrm{CS}$ & 0.477 & 0.464 & $<0.001$ & Accepted \\
\hline $\mathrm{H} 4$ & $\mathrm{CF} \rightarrow \mathrm{RG}$ & 0.681 & 0.377 & $<0.001$ & Accepted \\
\hline $\mathrm{H} 5$ & $\mathrm{CS} \rightarrow \mathrm{RI}$ & 0.388 & 0.293 & 0.002 & Accepted \\
\hline $\mathrm{H} 6$ & $\mathrm{CT} \rightarrow \mathrm{RI}$ & 0.370 & 0.276 & 0.003 & Accepted \\
\hline $\mathrm{H} 7$ & $\mathrm{CS} \rightarrow \mathrm{CT}$ & 0.378 & 0.293 & 0.005 & Accepted \\
\hline $\mathrm{H} 8$ & $\mathrm{RG} \rightarrow \mathrm{RI}$ & 0.181 & 0.097 & $<0.001$ & Accepted \\
\hline $\mathrm{H} 9$ & $\mathrm{RG} \rightarrow \mathrm{CS}$ & 0.011 & 0.005 & 0.362 & Rejected \\
\hline
\end{tabular}


Customer satisfaction (CS) was significantly affected by regret (RG). Therefore, only site quality and the confirmation variables had a significant influence on customer satisfaction. In addition, path coefficient differences can be used to sort variables based on their strongest influence. All other paths with their associated hypotheses were accepted. Customer trust was affected by site quality and customer satisfaction; regret was affected by confirmation; and repurchase intention was affected by customer satisfaction, customer trust, and regret.

\section{DISCUSSION}

The results of the hypothesis testing showed that of the nine hypotheses tested, one had to be rejected, while eight could be accepted. The rejected hypothesis is the regret variable $(\beta=0.011, p>0.05)$ which was not significant for the customer satisfaction variable (CS).

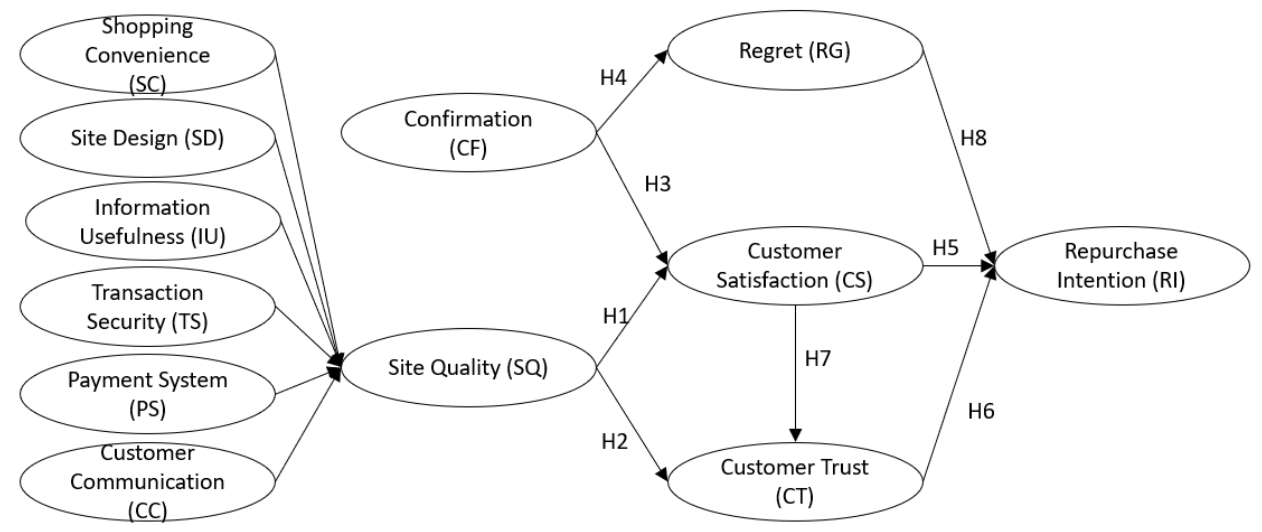

Figure 3 Final result of the research model

The results for $\mathrm{H} 1$ and $\mathrm{H} 2$ show that site quality proved to have a significant positive effect on customer satisfaction and customer trust. As mentioned above, site quality consists of six dimensions, namely shopping convenience, site design, information usefulness, transaction security, the payment system, and customer communication; the construct proved to have a significant positive effect on customer satisfaction and customer trust. The results of the analysis showed that the site design factor had the greatest weight value $(0.201)$, so it had the most significant effect on website quality. Users who have experienced a good website quality can develop improved satisfaction and trust. This also agrees with the results in [3], where the researchers that mentioned the quality of the website is an important marketing tool for encouraging positive behavior, as well as a significant factor for customer satisfaction and customer trust. In 
addition, when users are satisfied in completing transactions on the website, this can create a sense of trust toward the seller.

The results for $\mathrm{H} 5, \mathrm{H} 6$, and $\mathrm{H} 7$ indicated that consumer satisfaction and user trust have a positive and significant effect on the repurchase intention on the website. The higher the level of user satisfaction and user trust concerning the website, the higher the repurchase intention. This proves that customers who have bought something more than once feel satisfied and trust the seller. This is also in line with the results in [3], where the researchers mentioned higher customer satisfaction is an important factor in increasing customer trust.

The results for $\mathrm{H} 3, \mathrm{H} 4$, and $\mathrm{H} 8$ showed that confirmation has a positive effect on customer satisfaction, while it has a negative effect on regret; moreover, regret has a negative effect on repurchase intention. This shows that when the website can meet the customer expectations, the customer will feel satisfied and form repurchase intentions. Conversely, if it fails to meet customer expectations, then this will not only reduce the customers' satisfaction, but also cause them to have regret. Customers who have a bad experience will have a low intention to repurchase in the future. The results of this study also strengthen the ECM concerning confirmation variables' influence on satisfaction. This study is consistent with the research conducted in [11], where post-adoption confirmation positively affected the satisfaction; in other words, the satisfaction felt by the customer was due to confirmation. Furthermore, the findings in [12], which adopted expectancy confirmation and regret theory, supported the assumption of the ECM that confirmation will have a positive influence on satisfaction and repurchase intention, while it will negatively affects regret, which in turn, negatively affect repurchase intention.

From the results, this study found that regret does not have a significant influence on customer satisfaction. This means that regret relating to the shopping experience did not affect the customers' satisfaction levels. However, H8 posited that regret can influence the repurchase intention without first affecting satisfaction. In other words, customers can regret shopping on the website but still feel satisfied with the seller's offering. At the same time, the regret can decrease the repurchase intention for the website.

\section{IMPLICATIONS}

The results of the hypothesis testing from this research proved and empirically strengthened the ECM model. Furthermore, this study extended previous research on the dimensions of site quality from a technological perspective. Site quality and user experience affect the 
repurchase intention through the customer satisfaction as a mediation variable. In this variable, site design is the indicator with the greatest influence on the website quality. However, we failed to prove the effect of regret on satisfaction mentioned in [12].

The findings of this study can be implemented in the retail industry, especially on XYZ.com, where certain factors need to be improved to create a quality website, interesting content, and a positive user experience. For the site quality, the organization needs to ensure the quality of the website to provide a better shopping convenience, site design, useful information, transaction security, payment system, and customer communication. Some recommendations for site quality improvement are described in the following:

a. The first-order construct that most affected the quality of the website was the site design; thus, the company needs to create a team that focuses on developing its website design. This team can carry out periodic reviews of the website design involving user acceptance testing. This is in accordance with the results of the second-order construct evaluation, which showed that the site design had the highest value compared with the other variables, so it is the most influential variable concerning the website's quality;

b. Other payment options should be provided by working with third parties to create another payment gateway. This recommendation stems from the results of the second-order construct evaluation, which showed that the payment system had the highest value after site design; and

c. A discussion forum should be added to allow users to discuss related books or share their shopping experiences on the website. This stems from the results of second-order construct evaluation, which showed that customer communication has a sufficiently high value that a discussion forum would improve the website's quality.

Based on the results, customer satisfaction, customer trust, and regret significantly influence consumers repurchase intention. Company management can increase customer satisfaction and trust and decrease regret by improving the user experience. To accomplish this, the following steps can be implemented:

a. Provide customer service that can be contacted by customers quickly, so that their problems or questions can be resolved as soon as possible. For example, this can be done by providing a chat feature. This is in accordance with the results showing that customer 
satisfaction increases the repurchase intention. A chat feature is expected to prevent customer disappointment, as the feature can be used to ask questions and obtain answers in a timely fashion, so that customers will have full information about their purchase. This, in turn, will increase their satisfaction; and

b. Provide more varied shipping options so that customers can choose their preferred messenger. Currently, XYZ.com has only one courier delivery option; if the company were to provide various shipping options, this could increase both customer satisfaction and customer trust.

When these steps are implemented, they are expected to trigger satisfaction and trust; as a result, users repurchase intention on this website will increase. This can certainly augment the number of returning customers, thereby increasing the company's profits.

\section{CONCLUSION}

Based on the data analysis in this study, the factors that affect repurchase intention are site quality, confirmation, customer satisfaction, and regret. Customer satisfaction, customer trust, and regret are factors that directly affect the repurchasing intention; the factors that do not directly affect the repurchasing intention are the site quality and confirmation. In addition, the results of the data analysis showed that site quality is a technological dimension with a positive influence on the repurchase intention, mediated by customer satisfaction and customer trust. Future research can be done by testing the model for other industries to know the pattern of consumer shopping behavior in Indonesia comprehensively.

\section{REFERENCES}

[1] S. Gupta and H. Kim, "The moderating Effect of transaction Experience on the decision Calculus in One-Line Repurchase," International journal of electronic commerce, pp. 127-158, 2007.

[2] J. B. Shao, Z. Wang and X. Long, "The Driving Factor of Customer Retention: Empirical Study on Bank Card," International Conference on Management Science \& Engineering (15th), 2008.

[3] J. I. Shin, K. H. Chung, J. S. Oh and C. W. Lee, "The effect of site quality on repurchase intention in internet shopping through mediating variables: The case of university students in south Korea," 2013. 
[4] A. Battacherjee, "Understanding information systems continuance: An expectation-confirmation model. MIS Quarterly, 25(3),," pp. 351-370, 2001.

[5] C. J. Anumba and K. Ruikar, "Electronic commerce in construction--trends and prospects Automation in Construction,", p. 265-275, 2002.

[6] APJII, "Survey APJI Penetrasi Pengguna Internet Indonesia 2016," jakarta, 2016.

[7] Statista, "e-Commerce Market Report in Indonesia," January 2018. [Online]. Available: https://www.statista.com/outlook/243/120/ecom merce/indonesia\#market-revenue.

[8] H. Chang and S. Chen, "The impact of online store environment cues on purchase intention: Trust and perceived risk as a mediator," Online Information Review, pp. 818-841, 2008.

[9] M. Quaddus and M. A. Hossain, Expectation-confirmation theory in information system research: A review and analysis. In Y. K. Dwivedi, M. R. Wade, \& S. L. Schneberger (Eds.), Information Systems Theory: Explaining and predicting our digital society, vol. 1 (Vol. 1, pp. 441-469)., New York: Springer New York, 2012.

[10] S. Homsud and S. Caveesuk, "An integrates model of customer repurchase intention in B2C E-Commerce," 2014.

[11] C. Wen, R. P. Victor and C. Xu, "An Integrated model for Customer Online Repuchase Intention," Faculty Research \& Creative Activity, 2011.

[12] C. Liao, H. Lin, M. Luo and S. Chea, "Factors influencing online shoppers repurchase intentions: The roles of satisfaction and regret," Information \& Management, 2017.

[13] Y. Hwang and D. J. Kim, "Customer self-service systems: The effects of perceived Web quality with service contents on enjoyment, anxiety, and e-trust.," Decision Support Systems, pp. 43, 746-760, 2007.

[14] Z. A. Bulut, "Determinants of repurchase intention in online shopping: a Turkish consumer's perspective," International Journal of Business and Social Science, pp. 6, 55-63, 2015.

[15] W. DeLone and E. McLean, "Measuring e-Commerce Success: Applying the DeLone \& McLean Information Systems Success Model," International Journal of Electronic Commerce/ Fall 2004, Vol. 9, pp. 31-47, 2004.

[16] M. Zeelenberg and R. Pieters, "A theory of regret regulation 1.0," Journal of Consumer Psychology, pp. 17(1), 3-18, 2007.

[17] J. F. Hair, G. T. Hult, C. Ringle and M. Sarstedt, A Primer On Partial Least Squares Structural Equation Modeling (PLS-SEM), California: SAGE, 2014. 
[18] I. Ghozali and H. Latan, Partial Lease square: Konsep, metode, dan aplikasi menggunakan program WarpPls 4.0, Semarang: Universitas Diponegoro, 2014.

[19] N. Kock, "Using WarpPLS in e-collaboration studies: Mediating effects, control and second order variables, and algorithm choices.," International Journal of e-Collaboration,, pp. 7(3), 1-13, 2011.

\section{APPENDIX}

\begin{tabular}{|c|c|c|}
\hline Constructs & Indicators & References \\
\hline \multirow{4}{*}{$\begin{array}{l}\text { Shopping } \\
\text { Convenience }\end{array}$} & The website is convenience to use. & \multirow[t]{4}{*}{ [3] } \\
\hline & $\begin{array}{l}\text { It takes a short time to shop through } \\
\text { the website. }\end{array}$ & \\
\hline & The order process is easy to follow. & \\
\hline & $\begin{array}{l}\text { First time buyer can conduct } \\
\text { transaction without much help. }\end{array}$ & \\
\hline \multirow[t]{4}{*}{ Site Design } & $\begin{array}{l}\text { The interface of the website is } \\
\text { visually attractive }\end{array}$ & \multirow[t]{4}{*}{ [3] } \\
\hline & $\begin{array}{l}\text { Choice and selection are clearly } \\
\text { defined in the website }\end{array}$ & \\
\hline & $\begin{array}{l}\text { The view of the website is } \\
\text { professional }\end{array}$ & \\
\hline & $\begin{array}{l}\text { Website interface make transaction } \\
\text { become faster and easier. }\end{array}$ & \\
\hline \multirow[t]{4}{*}{$\begin{array}{l}\text { Information } \\
\text { usefulness }\end{array}$} & $\begin{array}{l}\text { The website provides rich } \\
\text { information on product features and } \\
\text { quality. }\end{array}$ & \multirow[t]{4}{*}{ [3] } \\
\hline & $\begin{array}{l}\text { The website provides good } \\
\text { information about the products } \\
\text { offered. }\end{array}$ & \\
\hline & $\begin{array}{l}\text { The website provides useful } \\
\text { information about the product. }\end{array}$ & \\
\hline & $\begin{array}{l}\text { The website provides much } \\
\text { information about the product. }\end{array}$ & \\
\hline
\end{tabular}


(cont.)

\begin{tabular}{|c|c|c|}
\hline Constructs & Indicators & References \\
\hline \multirow[t]{4}{*}{$\begin{array}{l}\text { Transaction } \\
\text { security }\end{array}$} & $\begin{array}{l}\text { The website protects the customer's } \\
\text { payment information. }\end{array}$ & \multirow[t]{4}{*}[3]{} \\
\hline & $\begin{array}{l}\text { The website protects customers } \\
\text { personal information. }\end{array}$ & \\
\hline & $\begin{array}{l}\text { The website protects the customer's } \\
\text { e-mail address. }\end{array}$ & \\
\hline & $\begin{array}{l}\text { The website does not misuse } \\
\text { customer information }\end{array}$ & \\
\hline \multirow[t]{4}{*}{ Payment system } & $\begin{array}{l}\text { Ordering procedure at the website is } \\
\text { simple. }\end{array}$ & \multirow[t]{4}{*}{ [3] } \\
\hline & $\begin{array}{l}\text { Order and payment transaction are } \\
\text { easy to conduct. }\end{array}$ & \\
\hline & $\begin{array}{l}\text { I trust the payment system from the } \\
\text { website }\end{array}$ & \\
\hline & $\begin{array}{l}\text { The website claims payment is more } \\
\text { than it should be (measured in } \\
\text { reserve) }\end{array}$ & \\
\hline \multirow[t]{4}{*}{$\begin{array}{l}\text { Customer } \\
\text { communication }\end{array}$} & $\begin{array}{l}\text { Consumers can provide ideas or } \\
\text { complaints on the website. }\end{array}$ & \multirow[t]{4}{*}{ [3] } \\
\hline & The website has a good FAQ system. & \\
\hline & $\begin{array}{l}\text { Customers is provided to give } \\
\text { product ratings at the website. }\end{array}$ & \\
\hline & $\begin{array}{l}\text { This website gives freedom on } \\
\text { giving feedbacks among customers }\end{array}$ & \\
\hline \multirow[t]{3}{*}{ Confirmation } & $\begin{array}{l}\text { My shopping experience shopping at } \\
\text { website is better than I expected }\end{array}$ & \multirow[t]{3}{*}[11]{$[12]$} \\
\hline & $\begin{array}{l}\text { The level of service provided by the } \\
\text { website is better than I expected }\end{array}$ & \\
\hline & $\begin{array}{l}\text { Overall, my expectations of } \\
\text { shopping at the website are met. }\end{array}$ & \\
\hline \multirow[t]{3}{*}{$\begin{array}{l}\text { Customer } \\
\text { satisfaction }\end{array}$} & $\begin{array}{l}\text { I am satisfied with the offer at the } \\
\text { website }\end{array}$ & \multirow[t]{3}{*}[3]{$[11][12]$} \\
\hline & I am satisfied to shop at the website & \\
\hline & $\begin{array}{l}\text { I am satisfied with the products sold } \\
\text { on the website }\end{array}$ & \\
\hline
\end{tabular}


(cont.)

\begin{tabular}{|c|c|c|}
\hline Constructs & Indicators & References \\
\hline \multirow[t]{4}{*}{ Customer Trust } & $\begin{array}{l}\text { I believe the information provided by } \\
\text { the website }\end{array}$ & \multirow[t]{4}{*}{ [3] [11] } \\
\hline & $\begin{array}{l}\text { I trust the promise given in the } \\
\text { website }\end{array}$ & \\
\hline & $\begin{array}{l}\text { I believe at the products provided in } \\
\text { the website }\end{array}$ & \\
\hline & $\begin{array}{l}\text { I believe that store will send the } \\
\text { items I bought }\end{array}$ & \\
\hline \multirow[t]{3}{*}{ Regret } & I feel guilty shopping at the website & \multirow[t]{3}{*}{ [12] } \\
\hline & $\begin{array}{l}\text { I regret choosing shopping at the } \\
\text { website }\end{array}$ & \\
\hline & $\begin{array}{l}\text { I should have chosen to shop at } \\
\text { another store }\end{array}$ & \\
\hline \multirow[t]{3}{*}{$\begin{array}{l}\text { Repurchase } \\
\text { intention }\end{array}$} & $\begin{array}{l}\text { I would like to buy product from the } \\
\text { website once again. }\end{array}$ & \multirow[t]{3}{*}{ [3] [11] [12] } \\
\hline & $\begin{array}{l}\text { I will continuously purchase product } \\
\text { from the website }\end{array}$ & \\
\hline & $\begin{array}{l}\text { I would like to purchase product } \\
\text { from the website again }\end{array}$ & \\
\hline
\end{tabular}

